\title{
Mengapa Pendidikan Politik Elektoral Penting? Respon Penyelenggaraan Pemilu 2019
}

\author{
Awaluddin \\ Fakultas Ilmu Sosial dan Ilmu Politik Universitas Airlangga \\ e-mail: awaluddin-2017@ fisip.unair.ac.id
}

\begin{abstract}
Citizens legitimacy of the process and results of elections is a feature of democratic elections. The implementation of democratic elections will not be realized without the awareness and knowledge of citizens about the political rights of citizens, forms of citizen participation in elections, rights and obligations of citizens in elections, and intelligence of voters in determining their choices in elections. This study aims to find academic concepts about the urgency of electoral political education for citizens as a rospon after the implementation of the 2019 Election. The method used in this study is qualitative through literature studies and documentation related to the importance of political education for the people as voters. The results of this study are expected to contribute to the thinking of policy makers in the electoral field in the context of efforts to democratize elections in Indonesia.
\end{abstract}

\section{Keywords - Political Education, Elections, Citizens}

Abstrak - Legitimasi warga negara terhadap proses dan hasil Pemilu merupakan ciri dari penyelenggaraan Pemilu yang demokratis. Penyelenggaraan Pemilu demokratis tidak akan diwujudan tanpa kesadaran dan pengetahuan dari warga negara tentang hak-hak politik warga negara, bentuk partisipasi warga negara dalam Pemilu, hak dan kewajiban warga negara dalam Pemilu serta kecerdasan pemilih dalam menentukan pilihannya dalam Pemilu. Penelitian ini bertujuan untuk menemukan konsep akademis tentang urgensi pendidikan politik elektoral bagi warga negara sebagai rospon pasca penyelenggaraan Pemilu 2019. Metode yang digunakan dalam studi ini adalah kualitatif melalui studi literatur dan dokumentasi yang terkait dengan pentingnya pendidikan politk bagi rakyat sebagai pemilih. Hasil dari studi ini diharapkan dapat memberikan sumbangsih pemikiran bagi pembuat kebijakan dibidang kepemiluan dalam rangka upaya demokratisasi Pemilu di Indonesia.

Kata Kunci: Pendidikan Politik, Pemilu, Warga Negara

\section{PENDAHULUAN}

Indonesia baru saja menyelenggarakan demokrasi elektoral melalui pemilihan umum serentak tahun 2019. Demikian juga dengan hasil Pemilu. KPU telah menetapkan dan mengumumkan hasil pemilihan presiden dan wakil presiden yang dimenangkan pasangan Joko Widodo dan Ma'ruf Amin atas pasangan Prabowo Subianto dan Sandiaga Salahudin Uno. Sejumlah pengamat menilai bahwa penyelenggaran Pemilu 2019 lebih baik dibanding dengan pemilu-pemilu sebelumnya. Akan tetapi tidak sedikit praktisi maupun akademisi yang menanggap justru penyelenggaraan Pemilu 2019 lebih buruk dari Pemilu 2014.

Penilaian terhadap domokratisasi penyelenggaraan Pemilu tentu secara kualitatif setiap pihak memiliki parameter dan tolak ukur yang berbeda-beda. Namun terlepas dari itu, setiap pergelaran lima tahunan ini menimbulkan fenomena yang menarik untuk diperhatikan. Fenomena yang menunjukan adanya perhatian yang demikian besar, berupa perubahan kekuatan moril dan materiel dari masyarakat dan elit politik yang bisa menimbulkan "elektoralisme". Istilah elektoralisme oleh Fahrul Muzaqqi mendeskripsikan situasi dan praktek politik elektoral yang lebih mementingkan urusan menang kalah dalam Pemilu dengan mengorbankan tatanan nilai moral kultural dalam masyarakat.

Ketika kursi dan jabatan politik dianggap sangat penting bagi peserta Pemilu, maka segala daya upaya dilakukan untuk memenangkan kompetisi memperebutkan suara rakyat, termasuk harus melakukan malapraktek Pemilu. Hal ini seperti mana sebelum dan sesudah penyelenggaraan Pemilu 2019, ruang publik disajikan dengan berbagai penyebaran berita bohong (hoax), ujaran kebencian, politisasi agama, politik uang, ancaman kekerasan dan manipulasi hasil Pemilu menjadi tranding topic dihalaman berita berbagai media. Puncaknya hingga terjadi kerusuhan 
antara masa pendukung salah satu pasangan calon presiden dan wakil presiden dengan aparat keamanan yang menelan puluhan korban jiwa. Menurut data dari kementrian informasi dan kominikasi, sebanyak 549 berita bohong (hoax) politik terproduksi selama agusuts 2018 hingga April 2019.

Berbagai praktek yang dipandang immoral tersebut disadari atau tidak akan mengikis rasa persatuan dan kesatuan bangsa yang tentunya menjadi ancaman bagi kelangsungan hidup dalam bernegara. Tantangan ini menjadi "pekerjaan rumah" bagi generasi penerus bangsa dalam upaya mempertahankan cita-cita pendiri bangsa Indonesia. Berbagai problematik penyelenggaraan Pemilu di atas, menarik untuk ditelisik sehingga dalam kajian ini penulis berupaya menjawab pertanyaan mengapa pendidikan politik elektoral bagi pemilih pemula itu penting.

Pada bagian berikutnya, akan diuraikan beragam pemaknaan konsep hak-hak politik warga negara, bentuk partisipasi warga negara dalam Pemilu, pendidikan politik. Pada bagian selanjutnya akan diuraikan seberapa pentingnya pendidikan politik dalam Pemilu bagi warga negara.

\section{METODE PENELITIAN}

Dalam kajian ini penulis menggunakan metode pendekatan kualitatif melalui studi literature dan dokumentasi yang terkait dengan pentingnya pendidikan politik elektoral bagi rakyat Pemilih. Studi literature dilakukan dengan mengumpulkan dan mereview literature yang relevan dengan permasalahan yang dikaji, sedangkan dokumentasi dilakukan dengan mereview berbagai norma konstitusi, kebijakan perundang-undangan serta dokumen lainnya sebagai data sekunder yang menunjang pembahasan dan analisisnya

\section{PERSPEKTIF TEORI}

Secara etimologi kata "pendidikan" dalam bahasa inggris disebut dengan education. Dalam bahasa latin pendidikan disebut dengan educatum yang tersusun dari dua kata yaitu $e$ yang berarti perkembangan dari dalam keluar atau dari sedikit ke banyak, dan kata duco yang artinya perkembangan atau sedang berkembang. Jadi, secara etimologi pengertian pendidikan adalah proses mengembangkan kemampuan diri sendiri dan kekuatan individu. Sedangkan menurut Kamus Besar Bahasa Indonesia, pendidikan adalah proses pengubahan sikap dan tata laku seseorang atau kelompok orang dalam usaha mendewasakan manusia melalui upaya pengajaran dan pelatihan.
Untuk menjelaskan makna pendidikan secara substansial, Ki Hajar Dewantara merumuskan bahwa pendidikan umumnya berarti daya upaya untuk memajukan bertumbuhnya budi pekerti (kekuatan batin, karakter), pikiran (intelektual dan tubuh fisik); dalam taman siswa tidak boleh dipisahkan bagian-bagian itu agar suapaya kita memajukan kesempurnaan hidup, kehidupan dan penghidupan anak-anak yang kita didik, selaras dengan dunianya. Sementara dalam legal formal Undang-undang Nomor 20 Tahun 2003 tentang Sistem Pendidikan Nasional, menjelaskan pokok pikiran utama dalam pendidikan yaitu usaha sadar dan terencana untuk mewujudkan suasana belajar dan proses pembelajaran agar peserta didik aktif mengembangkan potensi dirinya sehingga memiliki kekuatan spritual keagamaan, pengendalian diri, kepribadian, kecerdasan, akhlak mulia, serta keterampilan yang diperlukan dirinya, masyarakat, bangsa dan Negara

Politik menurut Miriam Budiardjo adalah usaha untuk mencapai suatu masyarakat yang lebih baik daripada yang dihadapinya. Sejalan dengan itu, Peter Merkl mengatakan bahwa politik dalam bentuk yang paling baik adalah usaha mencapai sesuatu tatanan sosial yang baik dan berkeadilan (Miriam Budiardjo, 2008:15). Sementara elektoral atau pemilihan umum adalah merupakan bagian dari politik.

Politik elektoral diartikan sebagai sala satu sarana untuk menentukan orang-orang yang akan mewakili rakyat dalam menjalankan pemerintahan. G.J. Wolhoff mendefiniskan pemilu dengan memulai dari konsep demokrasi. Demokrasi berarti pemerintahan rakyat. Pemerintahan untuk rakyat, dan oleh rakyat seluruhnya. Dalam negara domkrasi, rakyat secara keseluruhan ikut serta dalam pemerintahan secara langsung maupun tidak langsung. Di dalam demokrasi tidak langsung atau demokrasi perwakilan rakyat memilih menurut salah satu sistem pemilihan untuk memilih wakil-wkilnya agar menjalankan atau turut serta dalam pemerintahan atas nama rakyat (Fajlurrahman Jurdi, 2018:2).

Definisi lain dari Ramlan Surbakti mengtakan bahwa Pemilu sebagai instrumen dirumuskan sebagai: (1) mekanisme pendelegasian sebagian kedaulatan dari rakyat kepada peserta Pemilu dan/atau calon anggota DPR, DPD, DPRD, Presiden dan Wakil Presiden, dan Kepala Daerah/Wakil Kepala Daerah untuk membuat dan melaksanakan keputusan politik sesuai dengan kehendak rakyat; (2) mekanisme perubahan politik mengenai pola dan arah kebijakan publik, dan/atau mengenai sirkulasi elite, secara periodik dan tertib; dan (3) mekanisme 
pemindahan berbagai macam perbedaan dan pertentangan kepentingan dari masyarakat ke dalam lembaga legislatif dan eksekutif untuk dibahas dan diputuskan secara terbuka dan beradab (Ramlan Surbakti, 2008:32). Pendapat berikutnya dari Jimly Asshiddiqie bahwa Pemilu adalah merupakan cara yang diselenggarakan untuk memilih wakil-wakil rakyat secara demokratis (Jimly Asshiddiqie, 2014:414).

Pesta demokrasi atau yang sering disebut dengan demokrasi elektoral merupakan keniscayaan bagi negara yang mengakui kedaulatan rakyat. Negara penganut prinsip kedaulatan rakyat disebut dengan negara demokrasi yang bercirikan pemerintah dari rakyat oleh rakyat dan untuk rakyat. Legalitas pengakuan terhadap kedaulatan rakyat termaktub dalan konstitusi UUD 1945 pasal 1 ayat (2) yang berbunyi "kedaulatan berada di tangan rakyat dan dilaksanakan menurut Undang-Undang Dasar." Implementasi kedaulatan rakyat dilakukan baik secara langsung maupun tidak langsung atau demokrasi perwakilan. Pada Demokrasi perwakilan, rakyat melaksanakan transfer kedaulatan dengan memilih pemimpin dan/wakil mereka pada Pemilu. Sehingga Pemilu merupakan mekanisme penyelesaian dan pendelegasian atau penyerahan kedaulatan kepada orang atau partai yang dipercayai (Sigit Pamungkas, 2010:23).

Dari rumusan diatas dapat ditarik suatu proposisi bahwa tujuan pendidikan politik elektoral untuk mengembangkan percayaan dan pengertian atas proses Pemilihan Umum. Hal ini mencakup penyampaian informasi kepada pemilih pada umumnya tentang hal-hal yang berkaitan dengan Pemilu, seperti UU Politik, UU Pemilu, UU Pemilihan Presiden dan mekanisme pemilihan, dan bagaimana proses pemberian suara pada hari Pemilu itu. Tujuan berikutnya adalah untuk memotifasi kelompokkelompok tertentu seperti pemilih perempuan, pemilih pemula, orang marginal dipedesaan dan tempat terpencil untuk mengambil bagian dalam Pemilu dengan memberikan penyuluhan tentang pentingnya suara individual (Akbar Kaelola, 2009:230)

\section{HASIL PENELITIAN}

\section{Hak Politik Warga Negara}

Dalam pengertian minimalis, demokrasi terdiri dari 2 (dua) unsur yaitu kontestasi dan partisipasi. Demokrasi dalam arti partisipasi menurut Robert A. Dahl adalah partisipasi untuk menentukan kebijakan dalam proses pemerintahan agar seluruh anggota memiliki hak yang sama dengan harus memenuhi kriteria: pertama, partisipasi aktif; kedua, persamaan suara; ketiga, pemahaman yang cukup; keempat, pengawasan terhadap pelaksanaan; dan lima, pelibatan orang dewasa (Robert A. Dahl, 2001: 63).

Dari kriteria diatas, jelas bahwa partisipasi politik tidak berdiri sendiri melainkan harus didukung oleh kesadaran politik, persamaan, pemahaman politik dan juga harus dilakukan oleh orang dewasa. Undang-Undan Pemilu mengatur penduduk dikatakan dewasa jika telah berusian 17 tahun atau lebih, atau sudah/pernah kawin. Kepada penduduk yang telah dianggap dewasa, memiliki hak politik baik untuk dipilih maupun hak untuk memilih.

Hak-hak politik warga negara dalam The Universal Declaration of Human Right (UDHM) PBB pada tahun 1948 Pasal 21 menyebutkan: ayat (1) setiap orang berhak turut serta dalam pemerintahan negaranya, secara langsung atau melalui wakil-wakil yang dipilih dengan bebas; ayat (2) setiap orang berhak atas kesempatan yang sama untuk diangkat dalam jabatan pemerintahan negaranya; dan ayat (3) kehendak rakyat harus menjadi dasar kekuadaan pemerintah, kehendak ini harus dinyatakan dalam pemilihan umum yang dilaksanakan secara berkala dan murni, dengan hak pilih yang bersifat umum dan sederajat, dengan pemungutan suara secara rahasia ataupun dengan prosedur lain yang menjamin kebebasan memberikan suara.

Rumusan berbeda dengan substansi hak-hak politik warga negara yang sama kembali dideklarsikan PBB melalui International Covenant on Civil and Political Rihts (ICCPR) tahun 1960. Pada pasal 25 ICPPR yang menyebutkan bahwa setiap warga negara harus mempunyai hak dan kesempatan, tanpa pembedaan apapun dan tanpa pembatasan yang tidak layak untu: (1) ikut serta dalam pelaksanaan urusan pemerintahan, baik secara langsung ataupun melalui wakil-wakil yang dipilih secara bebas; (2) memilih dan dipilih pada pemilihan umum berkala yang murni, dan dengan hak pilih yang universal dan sama, serta dilakukan melalui pemungutan suara secara rahasia untuk menjamin kebebasan menyatakan keinginan dari para pemilih; (3) memperoleh akses pada pelayanan umum di negaranya atas dasar persamaan dalam arti umum.

Norma dalam The Universal Declaration of Human Rights dan International Covenant on Civil and Political Rights diatas diratifikasi oleh Indonesia melalui Undang-Undang Nomor 12 Tahun 2005 tentang Pengesahan International Covenant on Civil and Political Rights (Kovenan Internasioanal tentang hakhak Sipil dan Poltik. Tidak hanya itu, 
penegasan tentang pengakuan hak-hak politik warga negara juga termaktub dalam konstitusi UUD 1945 pada bab X tentang warga negara dan penduduk serta pada bab XI tentang hak asasi manusia.

\section{Partisipasi Politik Elektoral}

Pengertian partisipasi dalam KBBI adalah turut berperan serta dalam suatu kegiatan. George dan Achilles mendefinisikan partisipasi politik sebagai kegiatan warga negara yang bertindak secara pribadi-pribadi dengan maskud untuk mempengaruhi pembuatan keptusan oleh pemerintah. Sejalan dengan itu, Herbert McClosky mengartikan partisipasi politik seagai kegiatan-kegaitan sukarela dan warga negara melalui mana mereka mengambil bagian dalam proses pemilihan penguasa, secara langsung atua tidak langsung (Yoyoh Rahaniah dan Efriza, 2017:271).

Terdapat berbagai bentuk partisipasi politik dalan bernegara. Menurut Dedi Irawan bentuk partisipasi politik terbagi menjadi 4 (empat) bagian yaitu: (1) voting atau pemberian suara dalam Pemilu; (2) kampanye politik; (3) aktifitas organsiasi; dan (4) kontak politik atau lobi politik. Sementara Michael Rush dan Philip Althoff merumuskan 9 (sembilan) tingakat partisipasi untuk menunjukan tinggi atau rendahnya partisipasi politik yang dilakukan warga negara, yaitu: (1) voting atau pemberian suara dalam Pemilu; (2) keikutsertaan dalam suatu diskusi politik; (3) keikutsertaan dalam kampanye politik, rapat umum, demonstrasi, dsb; (4) tercatat sebagai pengurus aktif dalam suatu ormas/LSM yang bernuansa politik; (5) menjadi anggota biasa dalam sebuah parpol; (6) menjadi pengurus aktif dalam sebuah parpol; (7) menjadi pengurus aktif dalam sebuah parpol; (8) secara profesional bekerja sebagai pencari jabatan politik atau jabatan administratif; (9) secara profesional menduduki jabatan politik di pemerintahan atau jabatan administratif.

Dari kedua pendapat di atas, menempatkan voting atau pemberian suara dalam Pemilu pada posisi teratas dari pada bentuk partisipasi lainnya. Hal ini dikandung makasud bahwa meskipun proses pemberian suara hanya dilakuan dalam waktu tertentu (periodisasi), namun mengambil peran yang penting dalam proses politik. Tidak hanya untuk menentukan siapa yang mewakili mereka, pemberian suara dalam Pemilu juga menentukan arah dan kebijakan dari pemerintah yang dilahirakan melalui Pemilu.

Beberapa fungsi Pemilu yang tulis oleh Fajlurrahman Jurdi dalam bukunya Pengantar Hukum Pemilu, adalah: Pertama, sebagai sarana pemilihan pejabat publik. Fungsi ini sebagai mekanisme pembatasan kekuasaan. Pembatasan kekuasaan tidak saja dimaknai dalam konteks cek and balances antar lembaga negara, tetapi juga yang paling hakiki aalah menghindari teralalu lamanya seseorang menempati jabatan publik lembaga negara. Karena semakin lama kekuasaan itu akan semakin tak terkontrol dan dapat menimbulkan otoriterisme. Kedua, Sarana pertanggungjawaban pejabat publik. Fungsi ini berhubungan erat dengan masa jabatan dan memperoleh kembali kekuasaan yang dimiliki. Jika pejabat publik yang dipilih melalui Pemilu bisa bekerja dengan baik, maka dengan sendirinya dapat dipilih kembali. Sementara jika dia tidak bisa bekerja dan tidak akuntabel maka dia dengan sendirinya tidak akan terpilih lagi melalui seleksi publik dalam Pemilu.

Ketiga, sebagai sarana pendidikan politik rakyat. Melaui Pemilu rakyat mengetahui dan memahami makna politik secara praktis, dimana politik adalah pertukaran ide, gagasan dan kepentingan yang saling mempengaruhi untuk diambil dalam bentuk keputusan yang nyata. Keempat, mengubah kebijakan. Sebagai mekanisme pergantian kekuasaan, maka bila kekuasaan mengalami perubahan maka kebijakan akan mengalami perubahan pula. Kelima, mengganti pemerintahan. Dengan bergantinya kekuasaan maka juga akan mengganti program dan kebijakan. Keenam, menyalurkan aspirasi daerah. Melalui mekanisme pemilu orang-orang yang tidak berada dipusat kekuasaan, atau orang-orang yang berada di daerah memiliki peluang yang sama untuk dipilih secara langsung dalam rangka mewakili daerahnya di tingkat nasional.

Di atas telah diuraikan bentuk hak-hak politik warga negara dan fungsi penyelenggaraan Pemilu, Lalu seperti apa bentuk partisipasi warga negara dalam Pemilu ? Berikut setidaknya 10 (sepuluh) bentuk partisipasi warga negara dalam proses penyelenggaraan Pemilu. (1) bekerjasama dengan KPU melaksanakan sosialisasi Pemilu; (2) melaksanakan pendidikan pemilih (voter education), (3) keterlibatan anggota partai politik dalam proses pemilihan pengurus partai politik; (4) partisipasi pemilih dalam memberikan suara pada Pemilu; (5) peliputan segalah kegaitan yang menyangkut penyelenggaraan Pemilu oleh wartawan dan aparat media; (6) memberikan dukungan aktif kepada peserta Pemilu/calon tertentu; (7) mengajak para pemilih lainnya untuk mendukung atau menyatakan keberatan atas alternatif kebijakan yang ditawarkan oleh penyelenggara Pemilu atau peserta Pemilu; (8) menyampaikan pengaduan tentang dugaan pelanggaran pemilu; (9) melakukan survey atas persepsi atau pendapat pemilih mengenai peserta Pemilu dan menyebarluaskannya 
kepada masyarakat; (10) melaksanakan dan menyebarluaskan hasil penghitungan suara (Ramlan Surbakti dan Didik Supriyanto, 2013:5).

\section{Pendidikan Politik Elektoral}

Definisi pendidikan atau sosialisasi politik adalah proses pembentukan sikap dan orientasi politik para anggota masyarakat. Melalui proses pendidikan politik inilah warga negara memperoleh sikap dan orientasi terhadap kehidupan politik yang berlansung dalam masyarakat (Ramlan Surbakti, 2015:150). Pendidikan politik di tujukan untuk meningkatkan dan mengembangkan kesadaran kehidupan berbangsa dan bernegara. Peningkatan pemahaman akan kesadaran kehidupan berbangsa dan bernegara akan mampu meningkatkan partisipasi secara aktif untuk membangun bangsa sesuai dengan arah dan cita-cita bangsa. Pandangan diatas, sejalan dengan pendapat Sumantri dan Affandi (1996) yang menyatakan bahwa maskud diselenggarakannya pendidikan politik pada dasarnya adalah untuk memberikan pedoman kepada warga negara guna meningkatkan kesadaran kehidupan berbangsa dan bernegara sesuai dengan arah dan cita-cita bangsa.

Pendidikan Politik berfungsi untuk memberikan pengertian kepada generasi muda supaya memahami nilai-nilai serta dinamika perpolitikan yang sedang berlangsung. Ini berarti bahwa pendidikan politik menekankan kepada usaha penghayatan nilai-nilai yang etis normatif, dengan menanamkan norma-norma yang merupakan landasan dan motivasi bangsa Indonesia serta dasar untuk membina dan mengembangkan diri supaya masyarakat bisa ikut serta berpartisipasi dalam kehidupan perpolitikan. Sementara Sumantri, mengatakan bahwapendididikan politik akan membentuk warga negara yang berkepribadian utuh, berketerampilan, sekaligus juga berkesadaran yang tinggi dan memahami apa itu warga negara yang baik, sadarakan hak dan kewajibannnya, serta memiliki rasa tanggung jawab yang dilandasi oleh nilai-nilai yang berlaku dalam kehidupan berbangsa dan bernegara (Sumantri, 2003.3).

Rusadi Kantraprawira (2006:54) memandang pendidikan politik sebagai salah satu fungsi struktur politik dengan tujuan untuk meningkatkan pengetahuan politik rakyat supaya mereka dapat berpartisipasi secara maksimal dalam suatu sistem politik. Pendidikan politik disini merupakan metode untuk melibatkan rakyat melalui partisipasi aktif mereka dalam menyalurkan tuntutan dan dikungannya terhadapat aktifitas, tindakan, kebijakan maupn institusi politik.
Dalam politik, seseorang tidak hanya dituntut untuk mengembangkan pengetahuan, tetapi juga harus mengembangkan aspek sikap dan keterampilan. Perpaduan ketiga aspek tersebut menurut Crick (2005) disebut dengan melek politik "political literacy". Keberhasilan pendidikan politik tentunya akan melahirkan masyarakat yang melek politik yang nantinya akan mampu berpartisipasi secara aktif dalam berbagai kegiatan politik dalam komunitasnya. Pendidikan politik tidak hanya dilaksankan melalui pembelajaran di persekolahan saja, melainkan juga dapat dilakukan melalui proses sosialisasi politik seperti kegiatan kursus, latifhan kememimpinan, diskusi serta keikutsertaan dalam berbagai forum pertemuan. Proses sosialisasi politik ini haruslah dilakukan secara luas, melibatkan banyak orang, dan dilaksanakan secara dialogis-interaktif, bukan indoktrinatif.

Efektifitas politik suatu bangsa berorientasi kepada semangat membangun bangsa sehingga setiap yang dilakukan baik dalam membuat kebijakan dan memilih pemimpin serta wakil rakyat selalu didasarkan pada perjuangan yang bertujuan kemakmuran rakyat dengan prinsip keadilan sosial bagi seluruh warganya. Praktek politik menunjukan jika budaya politik di suatu negara telah matang diantaranya jika menghargai perbedaan antar kelompok, dewasa dalam persaingan dan cara untuk memperoleh kekuasaan dicapai secara jujur dan adil serta mengedepankan moral sebagai budaya politik.

Pendidikan politik elektoral diarahkan agar warga melek terhadap Pemilu. Punya pengetahuan tentang sistem Pemilu yang dianut oleh negara, hak dan kewajiban warga negara dalam Pemilu, juga bentuk partisipasi warga negara dalam Pemilu yang pada gilirannya akan meningkatkan partisipasi dalam Pemilu. Lebih jauh dari itu, pendidikan politik elektoral akan meningkatkan kecerdasan pemilih dalam memilih calon pemimpin dan wakilnya dilembaga pemerintahan. Sejatinya, memilih pemimpin adalah karena mempertimbangkan profesionalitas, integritas, serta rencana kebijakan publik yang ditawarkan oleh calon pemimpin dan calon wakil rakyat.

Tidak kalah penting lagi, pendidikan politik akan menciptakan penyelenggaraan Pemilu yang Demokratis. Pendidikan politik yang mengarahkan pengetahuan tentang proses penyelenggaraan pemilu, penerapan asas Pemilu demokrasi (langsung, umum, bebas, rahasia, jujur, dan adil) serta pemilu berintegritas pada setiap proses 
penyelenggaraan Pemilu maka akan melahirkan kepercayaan yang tinggi terhadap proses dan hasil Pemilu oleh pemilik kedaulatan. Rakyat akan melegitimasi hasil Pemilu dan mendukung kebijakan publik yang dijalankan oleh pemerintah hasil Pemilu. Pengakuan dan dukungan masyarakat kepada pemerintah hasil Pemilu, akan menciptakan pemerintahan yang stabil sehingga pemerintah dapat mebuat keputusan dan menjalankan keputusan yang menguntungkan masyarakat umum.

\section{KESIMPULAN}

Pendidikan politik elektoral sangat dibutuhkan bangsa Indonesia dewasa ini. Penyelenggaran Pemilu 2019 yang diwarnai penyebaran berita bohong (hoax), ujaran kebencian, politisasi agama, politik uang, ancaman kekerasan dan manipulasi hasil Pemilu serta bentorakan antar pendukung yang hingga menelan korban jiwa adalah bentuk ketidakdewasaan warga negara dalam politik elektoral. Pengetahuan tentang proses penyelenggaraan Pemilu, hak dan kewajiban warga negara dalam Pemilu, bentuk partisipasi warga negara, dan kecerdasan pemilih dalam menentukan pilihan dalam Pemilu menjadi tujuan penting dalam melakukan pendidikan politik. Dengan begitu, akan menciptakan penyelenggaraan Pemilu yang demokratis, melahirkan kepercayaan yang tinggi terhadap proses dan hasil Pemilu dan pada gilirannya rakyat akan mendukung kebijakan publik yang jalankan pemerintah hasil Pemilu sebagai ciri dari negara demokratis, memperkuat integrasi bangsa, dan mewujudkan cita-cita pendiri bangsa dalam konstitusi UUD 1945.

\section{REFERENSI}

Asshidiqie, Jimly, 2014. Pengantar Ilmu Hukum Tata Negara, Jakarta: Rajawali Pers

Brownhill, Robert \& Smart, Patricia, 1989. Political Education. London and New York. Routledge

Budiardjo, Miriam, 2008. Dasar-Dasar Ilmu Politik, Jakarta: PT. Gramedia Pustaka Utama

Dahl, Robert A. 2001. Perihal Demokrasi: Menjelajahi Teori dan Praktek Demokrasi Secara Singkat, diterjemahkan oleh Zainyddin, Rahmat. Jakarta: Yayasan Obor Indonesia
Harsono, 2011. Pendidikan Untuk Semua, Dalam Publikasi Universitas Muhamadiyah Surakarta

Jurdi, Fajlurrahman, 2018. Pengant Hukum Pemilihan Umum, Jakarta: Kencana

Kaelola, Akbar, 2009. Kamus Istilah Politik, Yogyakarta: Cakrawala

Pamungkas, Sigit, 2010, Pemilu, Perilaku Pemilih dan Kepartaian, Yogyakarta: Intitute For Democracyand Welfarism.

Rohaniah, Yoyoh dan Efriza, 2017. Handbook Sistem Politik Indonesia, Menjelajah Teori dan Praktek, Malang: Intrans Publishing

Surbakti, Ramlan and Didik. 2013. Partisipasi Warga Masyarakat Dalam Proses Penyelenggaraan Pemilihan Umum. Jakarta: Kemitraan

Surbakti, Ramlan, 2015. Memahami Ilmu Politik, Jakarta: Kompas Gramedia

The Universal Declaration of Human Right (UDHM) PBB pada tahun 1948

International Covenant on Civil and Political Rihts (ICCPR) tahun 1960

Undang-Undang Dasar Negara Republik Indonesia Tahun 1945

Undang-undang Nomor 20 Tahun 2003 tentang Sistem Pendidikan Nasional

Undang-Undang Nomor 12 Tahun 2005 tentang Pengesahan International Covenant on Civil and Political Rights (Kovenan Internasioanal tentang hak-hak Sipil dan Poltik

https://www.kanalinfo.web.id/pengertianelektoral-dalam-demokrasi

https://silabus.org/pengertian-pendidikan/

https://mediaindonesia.com/read/detail/229106ancaman-pengeroposan-demokrasi 